\title{
GAMBARAN HARGA DIRI, CITRA TUBUH, DAN IDEAL DIRI REMAJA PUTRI BERJERAWAT
}

\author{
Dian Agustin ${ }^{1}$, Muhammad Khabib ${ }^{1}$, Hendra Adi Prasetya ${ }^{1}$ \\ ${ }^{1}$ Program Studi Ners, STIKES Kendal \\ dianagustin7411@gmail.com
}

\begin{abstract}
ABSTRAK
Jerawat merupakan masalah yang sering dialami remaja karena pada masa remaja terjadi perubahan hormonal. Jerawat akan mempengaruhi harga diri, citra tubuh, ideal diri pada remaja. Salah satu upaya untuk meningkatkan harga diri, citra tubuh, ideal diri terkait dengan munculnya jerawat dengan melakukan perawatan wajah. Desain deskriptif analisis dengan metode cross sectional. Sampel sebanyak 77 siswi dengan caraasidentil sampling. Hasil penelitian diperoleh responden yang melakukan perawatan wajah sebagian besar memiliki harga diri tinggi27 $(77,1 \%)$, citra tubuh positif 29 responden $(82,9 \%)$, dan ideal diri positif 27 responden $(77,1 \%)$. Sedangkan responden yang tidak melakukan perawatan wajah sebagian besar memiliki harga diri rendah $23(54,8 \%)$, citra tubuh positif $23(54,8 \%)$, ideal diri positif dan negatif yang seimbang sebesar $21(50,0 \%)$. Responden yang melakukan perawatan sebagian besar memiliki harga diri tinggi, citra tubuh positif, dan ideal diri positif. Sedangkan responden yang tidak melakukan perawatan sebagian besar memiliki harga diri rendah, citra tubuh positif, dan ideal diri seimbang positif dan negatif.
\end{abstract}

Kata kunci: Citra tubuh, Harga diri, ideal diri, Jerawat

\section{DESCRIPTION OF SELF-ESTEEM, BODY IMAGE, SELF IDEAL IN ADOLESCENTS}

\begin{abstract}
Acne is a common problem for teenagers becaused in adolescence hormonal changes occur. Acne will affects self-esteem, body image, self ideal in adolescents. One effort to improve self-esteem, body image, selfideal associated with the appearance of acne by doing facial treatment. Descriptive design analysis with cross sectional method. Sample of research were 77 female students by asidentil sampling. The result of the research showed the most respondents had high self esteem 27 (77,1\%), positive body image 29 respondents (82,9\%), and self positive ideal 27 respondents $(77,1 \%)$. While respondents who did not do facial treatment mostly have low self esteem 23 (54,8\%), positive body image 23 (54,8\%), balanced positive and negative ideal equal to 21 (50,0\%). The most of respondents do care had high self esteem, positive body image, and positive self ideal. While the most of respondents do not care had low self-esteem, positive body image, and positive self-balanced positive and negative.
\end{abstract}

Keywords: Acne, Body image, Self esteem, self ideal,

\section{PENDAHULUAN}

Konsep diri merupakan pandangan dan perasaan tentang diri. Persepsi tentang diri bersifat psikologis, sosial, dan fisik (Purwanto, 2015). Lima komponen konsep meliputi harga diri, ideal diri, citra tubuh, identitas diri dan peran, dimana dalam komponen-komponen tersebut akan mempengaruhi konsep diri terutama keadaan fisik pada usia remaja. Keadaan fisik berupa perubahan fisik seperti remaja yang mempunyai jerawat (Keliat, 2015).Remaja berjerawat memberi kesan psikologis buruk terutama pada remaja yang masih dalam rentang usia sekolah.Remaja berjerawat seringkali mempunyai masalah yang berkaitan dengan harga diri, citra tubuh dan ideal diri (Keliat, 2015).
Jerawat merupakan penyakit kulit yang mengenai unit pilosebasea yang ditandai pembentukan komedo, papul, pustul, dan nodul dengan berbagai tingkat keparahan berbeda-beda. Jerawat dapat disebabkan karena faktor keturunan, stres, kosmetik, iklim, pekerjaan, serta hormonal. Jerawat bukan penyakit gawat darurat tetapi dapat menimbulkan krisis percaya diri remaja. Krisis percaya diri pada remaja berjerawat merupakan dampak dari rendahnya harga diri, citra tubuh dan ideal diri remaja (Andrea, Emmy, dan Diane, 2012). Angka kejadian jerawat di Asia Tenggara pada tahun 2015 terdapat (40-80\%) pada usia remaja (Afriyanti, 2015). Menurut catatan Dermatologi Kosmetika Indonesia terjadi kenaikan penderita jerawat, pada tahun 2006 
mencapai angka (60\%), ditahun 2007 mengalami kenaikan hingga mencapai angka $(80 \%)$ dan tahun 2009 terjadi kenaikan mencapai angka (90\%). Tahun 2008 Poliklinik Kulit dan Kelamin RSUP Dr. Kariadi Semarang didapatkan data penderita jerawat sebanyak (15,3\%) (Indrawan dan Kusumastuti, 2013).

Keinginantampil cantik dan menarik serta melakukan perawatan merupakan tata laksana untuk meningkatkan harga diri, citra tubuh dan ideal diri remaja yang berjerawat. Terutama pada remaja putri yang melakukan perawatan wajah seperti memakai pelembab, pembersih wajah, fasial, spa, hingga ke dokter kecantikan (Pratiwi, 2013). Hal ini seiring dengan kepedulian penampilan fisik remaja ketika penampilan fisik saat masa perkembangan tidak sesuai yang diinginkan seperti halnya remaja yang memiliki wajah berjerawat maka akan timbul rasa tidak puas. Ketidakpuasan dalam penampilan fisik dapat menyebabkan harga diri, citra tubuh dan ideal diri yang negatif. Harga diri, citra tubuh, dan ideal diri remaja akan naik saat berpenampilan menarik dan memiliki wajah yang cantik di lingkungan sosial (Kusumawati dan Hartono, 2010).

Berdasarkan hal tersebut maka peneliti tertarik melakukan penelitian untuk mengetahui "Gambaran harga diri, citra tubuh, dan ideal diri remaja putri berjerawat yang melakukan perawatan dan tidak melakukan perawatan di SMK Bhakti Persada Kendal"

Penelitian ini menggunakan desain deskriptif analisis dengan metode cross sectional yang dilaksanakan di SMK Bhakti Persada Kendal bulan Februari 2017. Sampel yang digunakan sebanyak 77 remaja putri berjerawat. Pengambilan sampel dengan cara asidentil sampling. Pengumpulan data dilakukan dengan menggunakan kuesioner terdiri dari 5 kuesioner yaitu kuesioner karakteristik responden, kuesioner harga diri sebanyak 6 pernyataan, citra tubuh sebanyak 6 pernyataan, ideal diri sebanyak 6 pernyataan, dan kusioner perawatan wajah sebanyak 10 pernyataan. Analisa data yang digunakan adalah univariat.Hasil uji validitas dari 4 kuesioner didapatkan nilai $\mathrm{r}$ hitung $<0,444$. Hasil uji reliabilitas untuk kuesioner tentang harga diri adalah 0,619, kuesioner citra tubuh 0,731, kuesioner ideal diri 0,699, dan kuesioner perawatan wajah 0,792 .

\section{HASIL}

Data responden berdasarkan usiayang melakukan perawatan dan tidak melakukan Perawatan menunjukkan bahwa rata-rata usia responden yang melakukan perawatan berusia 15,91 tahun, minimal 15 tahun, maksimal 17 tahun standar deviasi 0,853 tahun. Untuk estimasi interval 95\% rata-rata usia responden berada pada selang 15,62 s/d 16,21. Sedangkan rata-rata usia responden yang tidak melakukan perawatan yaitu 15,89 tahun, minimal 15 tahun, maksimal 17 tahun standar deviasi 0,775 tahun. Estimasi interval $95 \%$ rata-rata usia responden berada pada selang 15,66 s/d 16,12. Adapun data responden berdasarkan usia yang melakukan perawatan dan tidak melakukan Perawatan dapat dilihat pada tabel 1.

Tabel 1.

Usia responden $(\mathrm{n}=77)$

\begin{tabular}{lcccc}
\hline \multicolumn{1}{c}{ Variabel } & Mean + St.Deviation & Min & Max & 95\%CI \\
\hline Usia yang Perawatan & $15,91+0,853$ & 15 & 17 & $15,62-16,21$ \\
\hline Usia yang Tidak Perawatan & $15,89+0,775$ & 15 & 17 & $15,66-16,12$ \\
\hline
\end{tabular}

Tabel 2.

Kelas yang Melakukan Perawatan dan Tidak Melakukan Perawatan $(\mathrm{n}=77)$

\begin{tabular}{ccccc}
\hline Kelas & \multicolumn{2}{c}{ Perawatan } & \multicolumn{3}{c}{ Tidak Perawatan } \\
\cline { 2 - 5 } & $\mathrm{f}$ & $\%$ & $\mathrm{f}$ & $\%$ \\
\hline X & 14 & 40,0 & 18 & 42,9 \\
XI & 10 & 28,6 & 14 & 33,3 \\
XII & 11 & 31,4 & 10 & 23,8 \\
\hline Total & 35 & 100,0 & 42 & 100,0 \\
\hline
\end{tabular}


Tabel 3.

Data Responden Berdasarkan Responden yang Melakukan Perawatan dan Tidak Melakukan Perawatan $(n=77)$

\begin{tabular}{lccc}
\hline & Variabel & $\mathrm{f}$ & $\%$ \\
\hline Perawatan & 35 & 45.5 \\
Tidak Perawatan & 42 & 54.5 \\
\hline Total & 77 & 100,0 \\
\hline
\end{tabular}

Tabel 4.

Data Responden Berdasarkan Harga Diri, Citra Tubuh, Ideal Diri Responden yang Melakukan Perawatan dan Tidak Melakukan Perawatan $(\mathrm{n}=77)$

\begin{tabular}{lcccc}
\hline Variabel & \multicolumn{2}{c}{ Perawatan } & \multicolumn{2}{c}{ Tidak Perawatan } \\
\cline { 2 - 5 } & $\mathrm{f}$ & $\%$ & $\mathrm{f}$ & $\%$ \\
\hline Harga Diri & & & 23 & 54,8 \\
\hline Rendah & 8 & 22,9 & 19 & 45,2 \\
Tinggi & 27 & 77,1 & 42 & 100,0 \\
\hline Total & 35 & 100,0 & & 45,2 \\
\hline Citra Tubuh & & & 19 & 54,8 \\
\hline Negatif & 6 & 17,1 & 23 & 100,0 \\
Positif & 29 & 82,9 & 42 & \\
\hline Total & 35 & 100,0 & & 50,0 \\
\hline Ideal Diri & & & 21 & 50,0 \\
\hline Negatif & 8 & 22,9 & 21 & 54,5 \\
Positif & 27 & 77,1 & 42 & \\
\hline Total & 35 & 100,0 & &
\end{tabular}

\section{PEMBAHASAN}

Harga Diri Remaja Putri Berjerawat yang Melakukan Perawatan dan Tidak Melakukan Perawatan Wajah

Hasil penelitian menunjukkan bahwa remaja berjerawat yang melakukan perawatan wajah mayoritas memiliki harga diri tinggi. Harga diri tinggi pada remaja muncul setelah melakukan perawatan wajah. Hal ini diperkuat dengan penelitian yang dilakukan oleh Suryanti (2013) tentang hubungan harga diri dengan perawatan wajahyang menyatakan bahwa ada hubungan harga diri dengan perawatan wajah pada remaja putri berjerawat.

Hasil penelitian juga diketahui bahwa remaja berjerawat yang melakukan perawatan memiliki harga diri rendah.Hal ini menunjukkan bahwa remaja memiliki penilaian negatif terhadap dirinya sendiri.Sesuai dengan teoriYosep dan Sutini (2010) yang menyatakan bahwa individu yang tidak puas dengan karakteristik dan kemampuan-kemampuannya, sehingga akan menumbuhkan rasa tidak nyaman terhadap keberadaan dirinya di lingkungan sosial yang ditunjukkan dengan perasaan negatif tentang tubuhnya sendiri.
Hasil penelitian menunjukkan remaja berjerawat yang tidak melakukan perawatan wajah sebagianmemiliki harga diri tinggi. Hal ini terjadi karena remaja menilai dirinya baik sehingga akan dapat menyesuaikan diri dengan baik tanpa mengalami hambatan meski berjerawat dan tidak melakukan perawatan. Sesuai dengan teori Partosuwido (2006) tentang Penyesuaian diri mahasiswa dalam kaitannya dengan konsep diriyang menyatakan bahwa remaja yang memiliki harga diri tinggi maka penyesuaian dirinya akan tinggi pula begitu juga sebaliknya, remaja yang memiliki harga diri rendah maka penyesuaian dirinya juga akan rendah.

Hasil penelitian juga menunjukkan remaja yang tidak melakukan perawatan memiliki harga diri rendah. Sesuai dengan teori Keliat, (2015) yang menyatakan bahwa keadaan fisik dapat berpengaruh pada psikologis remaja terutama pada harga dirinya. Remaja yang memiliki keadaan fisik kurang menarik cenderung memiliki harga diri rendah dibandingkan dengan remaja yang memiliki kondisi fisik menarik. 


\section{Gambaran Citra Tubuh Remaja Putri Berjerawat yang Melakukan Perawatan dan Tidak Melakukan Perawatan}

Hasil penelitian menunjukkan bahwa remaja berjerawat yang melakukan perawatan wajahsebagian besar memiliki citra tubuh positif. Citra tubuh positif terjadi karena responden memiliki hubungan interpersonal yang baik sehingga mempengaruhi konsep diri termasuk mempengaruhi bagaimana perasaan terhadap penampilan fisik. Sejalan dengan teori Cash (2002) dalam Indika (2010) yang menyatakan bahwa salah satu faktor yang mempengaruhi citra tubuh adalah hubungan interpersonal.

Hasil penelitian juga menunjukkan bahwa remaja berjerawat yang melakukan perawatan memiliki citra tubuh negatif. Sejalan dengan teori Banon, Dalami, Farida, Rochimah dan Suliswati (2009) yang menyatakan bahwa citra tubuh mempunyai pengaruh yang cukup besar terhadap perilaku individu yaitu individu akan bertingkah laku sesuai dengan citra tubuh yang dimiliki. Individu yang memiliki citra tubuh yang positif akan mengembangkan perilaku yang positif sesuai dengan caranya memandang diri di lingkungan. Sebaliknya individu yang memiliki citra tubuh negatif akan mengembangkan perilaku yang negatif sesuai dengan caranya memandang diri di lingkungan.

Hasil penelitian menunjukkan bahwa remaja yang tidak melakukan perawatan mayoritas memiliki citra tubuh positif.Penelitian ini didukung dengan teori Melliana (2006) yang mengemukakan bahwa cara berpikir yang positif atau negatif merupakan hal terpenting dalam meningkatkan atau menurunkan citra tubuh seseorang. Individu yang berpikir positif terhadap tubuhnya akan memiliki citra tubuh yang positif yang kemudian mengarahkannya pada rasa puas terhadap tubuhnya.

Hasil penelitian menunjukkan remaja putrid berjerawat yang tidak melakukan perawatan wajah sebagian memiliki citra tubuh negatif. Hal ini terjadi karena remaja yang mempunyai jerawat memberi kesan psikologis yang buruk apalagi yang tidak melakukan perawatan wajah dan sebagian besar remaja putri memiliki perasaan yang negatif terhadap diri sendiri. Hasil ini sejalan dengan penelitian yang dilakukan oleh Anggraini (2012) tentang hubungan gambaran diri dengan interaksi sosial pada remaja yang berjerawat (Acne Vulgaris) yang menyatakan bahwa $(64,6 \%)$ memiliki gambaran diri negatif dan $(56,3 \%)$ memiliki interaksi sosial yang buruk pada remaja yang mempunyai jerawat yang tidak melakukan perawatan.

\section{Gambaran Ideal Diri Remaja Putri Berjerawat yang Melakukan Perawatan dan Tidak Melakukan Perawatan}

Hasil penelitian menunjukkan bahwa remaja berjerawat yang melakukan perawatan mayoritas memiliki ideal diri tinggi. Hal Ini terjadi karena remaja yang melakukan perawatan wajah banyak yang memiliki penilaian positif.Sesuai dengan teori yang dimiliki oleh Banon, Dalami, Farida, Rochimah dan Suliswati (2009) yang menyatakan bahwa individu yang memiliki ideal diri yang positif akan mengembangkan perilaku yang positif sesuai dengan caranya memandang diri di lingkungan. Sejalan dengan penelitian yang dilakukan oleh Khoeriyah (2010) yang menyatakan bahwa sebagian besar siswa yang mempunyai jerawat di kelas $\mathrm{X}$ dan XI di MAN 1 Semarangmemiliki ideal diri baik sebanyak 76 responden $(50,3 \%)$.

Hasil penelitian juga menunjukkan bahwaremaja putri yang tidak melakukan perawatan wajah memiliki ideal diri positif dan negatif dengan jumlah dan persentase yang sama. Hal ini menunjukkan bahwa remaja putri yang tidak melakukan perawatan wajah sebagian memiliki ideal diri positif dan sebagian negatif. Ini terjadi karena penilaian ideal diri positif dan negatif tergantung dari diri remaja sendiri dalam mempersepsikan dirinya tentang bagaimana dia seharusnya berperilaku sesuai dengan standar pribadi. Sejalan dengan teori Stuart \& Sundden (2001) dalam Purwanto (2015) menyatakan bahwa ideal diri merupakan persepsi individu tentang bagaimana dia harus berperilaku sesuai dengan standar pribadi, aspirasi, tujuan, atau nilai personal. Penilaian ideal diri positif atau negatif tergantung dari caranya memandang diri di lingkungan. Remaja yang menilai dirinyapositif maka akan memiliki ideal iri yang positif, sebaliknya remaja yang menilai dirinyanegatif maka akan memiliki ideal diri yang negatif (Keliat, 2015).

\section{SIMPULAN DAN SARAN}

\section{Simpulan}

Berdasarkan hasil penelitian tentang "Gambaran Harga Diri, Citra Tubuh, Dan Ideal Diri Remaja Putri Berjerawat yang Melakukan Perawatan dan Tidak Melakukan Perawatan di SMK Bhakti Persada Kendal" dapat disimpulkan karakteristik responden berdasarkan usia menunjukkan rata- 
rata usia responden yang melakukan perawatan 15,91tahun, sedangkan rata-rata usia yang tidak melakukan perawatan 15,89 tahun. Berdasarkan kelas menunjukkan dari kelas X sampai XII, responden yang paling banyak melakukan perawatan dan tidak perawatan terdapat pada kelas X.Harga diri, citra tubuh, dan ideal diri remaja putri berjerawat yang melakukan perawatan wajah menunjukkan bahwa sebagian besar responden memiliki harga diri tinggi,citra tubuh positif, dan ideal diri positif. Sedangkan responden yang tidak melakukan perawatan wajahsebagian besar memiliki harga diri rendah, citra tubuh positif, ideal diri positif dan negatif yang seimbang.

\section{Saran}

Hasil penelitian ini dapat menjadikan sebagai kajian dalam pengembangan ilmu pengetahuan di bidang keperawatan dan memberi kontribusi teoritis khususnya mengenai gambaran harga diri, citra tubuh, dan ideal diri remaja putri berjerawat. Penelitianselanjutnya dapat menyempurnakan hasilpenelitian ini dengan caramenambahkan dan menggunakan variabel lain seperti: lingkungan sekitar, pola asuh, sosial ekonomi dan pengalaman.

\section{DAFTAR PUSTAKA}

Afriyanti, R.N. (2015). Akne Vulgaris Pada Remaja. J Majority. 4(6): 102-109.

Andrea, L.Z., Emmy M.G., \& Diane M.T. (2012). Acne Vulgaris And Acne Iformeruptions In Dermatologi In General Medicine.NewYork: Mc GrawHillCompanies, 1 (8), 1264-1279.

Anggraini, D., (2012). Hubungan Gambaran Diri Dengan Interaksi Sosial Pada Remaja Yang Berjerawat (Acne Vulgaris) Di SMAN 3 Padang. http://repo.unand.ac.id/140.

Banon, E., Dalami, E., Farida, P., Rochimah., dan Suliswati (2009). Asuhan keperawataan jiwa dengan masalah psikososial. Jakarta: Trans Info Media.

Depkes. (2010). Kesehatan remaja: problem dan solusinya. Jakarta: Salemba Medika.

Ghufron, M. N. (2010). Teori -teori psikologi. Yogyakarta: Ar-Ruzz Media.

Indrawan, N dan Kusumastuti, A.C. (2013). Hubungan Asupan Lemak Jenuh Dengan
Kejadian Akne Vulgaris.Journal of
Nutrition Collage, 2 (4), 579.

Indika, K., (2010). Gambaran Citra Tubuh Pada Remaja Yang Obesitas.

Keliat, B. A., (2015). Prinsip dan praktik keperawatan jiwa. Jakarta: Elsevier.

Khoeriyah, F. (2010). Gambaran Konsep Diri Remaja Putri Yang Mempunyai Jerawat Di MAN 1 Semarang. Skripsi Universitas Muhammadiyah Semarang.

Kusumawati, F., dan Hartono, Y., (2010). Buku ajar keperawatan jiwa. Jakarta: Salemba Medika.

Melliana, A.S. (2006). Menjelajah tubuh: perempuan dan mitor kecantikan. Yogyakarta : LKis.

Ompi, E.E., David, L., dan Opod, H. (2015). Hubungan Tingkat Kepercayaan Diri Dengan Jerawat (Acne Vulgaris) Pada Remaja Di SMA Manado. http://ejournal.unsrat.ac.id/index.php/ebiom edik/article/view/11049.

Partosuwido, S.R. (2006). Penyesuaian Diri Mahasiswa Dalam Kaitannya Dengan Konsep Diri, Pusat Kendali Dan Status Perguruan Tinggi. Jurnal Psikologi Sosial $1,32-47$.

Pratiwi. (2013). Pegobatan jerawat dan tips pemakaian kosmetik. Yogyakarta: Platinum.

Purwanto, T., (2015). Buku ajar keperawatan jiwa. Yogyakarta: Pustaka Pelajar.

Ridwan, A., Astutik, W.S., dan Astutik, Y.N., (2010). Hubungan Tingkat Pengetahuan Dengan Konsep Diri Remaja Putri Yang Mengalami Jerawat (Acne Vulgaris).Jurnal AKP, (1), 19-21.

Suryanti, R.(2013). Hubungan Harga Diri Dengan Perawatan Wajah Pada Remaja Putri (Usia 16-19 Tahun) Yang Berjerawat Di SMA PGRI 01 Kendal. SkripsiSTIKes Kendal.

Yosep, I., dan Sutini, T. (2010). Buku ajar keperawatan jiwa. Jakarta: Rafika Adibta. 